\title{
Residual Risk
}

National Cancer Institute

\section{Source}

National Cancer Institute. Residual Risk. NCI Thesaurus. Code C142669.

Risk that remains after risk control measures have been taken. 